\title{
PROPERTY RIGHTS IN ASSETS AND RESISTANCE TO TENDER OFFERS
}

\author{
David D. Haddock, Jonathan R. Macey, and \\ Fred S. McChesney*
}

7 HE recent spate of highly publicized hostile tender offers has prompted questions about the proper reaction of target firm management to takeover bids. Traditionally, the law has not constrained management's ability to resist acquisition. To the contrary, courts recognize not just "a large reservoir of authority" in management to respond to takeover bids, but "an obligation to determine whether the offer is in the best interests of the corporation and its shareholders," and to resist if it is not.1

Particularly since the publication of an important article on the issue by Frank Easterbrook and Daniel Fischel, ${ }^{2}$ however, the wisdom of allowing managerial resistance has been challenged. All else being equal, resistance by any target firm reduces the bidder's net

* The authors are all associate professors at Emory University, teaching either in the Economics Department or at the School of Law. Macey is currently Visiting Associate Professor at the University of Virginia School of Law; McChesney is Visiting Associate Professor and John M. Olin Fellow in Law and Economics at the University of Chicago Law School. We received valuable comments from Henry Butler, William Carney, Louis De Alessi, Frank Easterbrook, Daniel Fischel, David Friedman, Charles Goetz, Clifford Holderness, Roger Meiners, Richard Posner, David Schap, and Alan Schwartz; from the participants in presentations made at the University of Chicago, Cornell University, and Emory University; and from participants in presentations made at the 1986 Western Economic Association meetings and the Conference on the Economics of Corporate and Capital Markets Law at Harvard University. As we hope is clear from these lengtby acknowledgements, the abundant citations helow and the lengthy reference list appended to our paper, we have benefited considerably from the many economists and lawyers who have addressed many of the topics we consider here. Distinguishing individual marginal products, as always, is difficult.

1 Unocal Corp. v. Mesa Petroleum Co., 493 A.2d 946, 953-54 (Del. 1985); see also infra note 49 (courts' discussions of mandatory managerial passivity in the face of takeovers). For the purposes of this article, "management" refers to firms' boards of directors and nonboard decision-makers; the interests of the two groups are assumed to coincide.

2 Easterbrook \& Fischel, The Proper Role of a Target's Management in Responding to a Tender Offer, 94 Harv. L. Rev. 1161 (1981) [hereinafter Proper Role]. For elaboration of the basic model see Easterbrook \& Fischel, Auctions and Sunk Costs in Tender Offers, 35 Stan. L. Rev. 1 (1982) [hereinafter Auctions]. 
expected returns. Consequently, it is argued, other potential targets would face a greater likelihood of an advantageous takeover, and all firms would receive greater monitoring, if resistance were impermissible. ${ }^{3}$ In addition, it is urged, managers could not be trusted to seek a proper level of monitoring even if it were attainable, as agency problems are apparently insurmountable when managers' jobs are on the line. ${ }^{4}$ The Easterbrook-Fischel school therefore would ban managerial resistance to tender offers.

The opposition to managerial resistance is troubling. In the paradigm market, sellers (or their agents) are permitted to reject initial offers and bargain for higher ones. Sellers cannot bargain if they cannot reject an offer. The no-bargaining proposal for shares thus raises fundamental economic issues of considerable significance outside the corporate sphere. Resolution of these issues requires a more general understanding of the functions of property and of bargaining rights for assets traded in "thin" markets. Such an understanding is the objective of this article.

Part I shows that the market for corporate control is similar to other markets where bargaining-resistance-is the norm. In such markets, important benefits arise from allowing asset owners (including corporate shareholders) to bargain freely. Bargaining garners for sellers a greater share of the gains from exchange, and thus enhances owners' initial incentives to make value-maximizing investments in an asset.

The logical structure of Part I can be summarized point by point:

(1) The ability to bargain is tantamount to the right to resist relinquishing an entitlement;

(2) the expected strength of future bargaining rights affects the magnitude of the present investment one is prepared to make to enhance the value of an entitlement, with stronger bargaining rights implying greater willingness to invest;

(3) bargaining over an exchange of entitlements is symmetrical, so that strengthening the bargaining position of one party (here, bidders) simultaneously weakens the bargaining position of the other party (targets); and hence,

(4) the proposed no-resistance rule might indeed augment invest-

3 Proper Role, supra note 2, at 1176-77.

Id. at 1175. 
ments in search by prospective bidders, but it would do so at a cost-it would simultaneously retard investments by prospective targets.

Ordinarily, one does not expect that owners of property rights will benefit if those rights are weakened. For a weakening of rights to benefit the owner, there must exist some market failure that cannot be overcome by voluntary contract. It is alleged that bargaining creates just such a failure in the market for corporate control. Targets' resistance to takeover bids, it is claimed, imposes external costs on other firms because those other firms receive less monitoring from bidders. ${ }^{5}$

Part II examines this supposed market failure. It points out that external effects are ubiquitous, but that if the legislature or judiciary is primarily interested in the public welfare, only a subset of these effects merits legal intervention. Several additional theoretical and empirical criteria must first be satisfied, before intervention is warranted. ${ }^{6}$ Yet, in the present debate about tender offer resistance, few of these criteria have been recognized or empirically investigated. The conditions necessary to justify intervention to eliminate an externality are stringent. It is by no means obvious that those conditions are met where resistance to tender offers is concerned.

If the argument through Part II is accepted, then the wisdom of the Easterbrook and Fischel proposal is seen to hinge on several uninvestigated premises. Of particular interest would be a comparison between the two effects a no-resistance rule might have: increased bidder search, and decreased investment in targets. Because the gain from increased search need not exceed the loss from decreased target investment, the reserved judicial response that has greeted the no-resistance proposal is in fact appropriate.

Logically, then, Parts I and II are the linchpins of the argument. Part III focuses on one of the conditions necessary to justify intervening against an externality, the requirement that the costs of private internalization exceed the costs of public intervention. We point out that:

Id. at 1176-77.

- See Buchanan \& Stubblebine, Externality, 29 Economica 371 (1962). 
(1) mechanisms exist that permit an individual target to alter its own bargaining rules implicitly, thus achieving the level of monitoring desired;

(2) targets have an incentive to make such alterations as long as increased bidder investments add greater value than the value of target investments lost; and,

(3) consequently, the cost to a firm of achieving the level of monitoring it desires (i.e., of avoiding any externality from other firms' resistance) seems modest.

When these private contract costs are contrasted with the costs of a mandatory no-resistance rule, therefore, such a rule appears inadvisable. Voluntary contracting seems able to cope with any losses arising from the perceived externality. Admittedly, some owners may prefer a binding no-resistance policy to attract greater attention from bidders. If so, they can announce and credibly bond a promise to constrain resistance, thus achieving contractually their preferred level of monitoring and bidding. Few, if any, firms do this. Consequently, as one would expect when the law weakens property rights, the majority of asset owners would be harmed by legal compulsion to adopt a no-resistance rule.

Part IV considers the agency cost objection to permitting resistance to tender offers. Initial entrepreneurs going public maximize their personal gains by maximizing the net present value of the firm, i.e., by considering both the costs and the benefits of various control techniques available to the public firm, including use of managerial agents. An agency "problem" would seem to exist in corporate control matters if analysts focus solely on the cost side. But the use of agents, even in the context of corporate control, has its benefits. The proper response to agency costs is not to eradicate them; that can be done only by eliminating the use (and thus the benefits) of agents. The appropriate response is to structure agency contracts optimally, so as to maximize the benefits net of costs. There is considerable evidence that firms facing the prospect of agency costs do just that.

The article concludes, in Part V, by noting that new law may indeed be called for, though not that proposed by Easterbrook and Fischel. Instead, new law may be desirable to enhance the ability of private parties to internalize the effects of any relevant externalities in the market for corporate control. The distinction between this proposal and that of Easterbrook and Fischel is the distinction between expanded choice and compulsion. 


\section{Bargaining and Property Rights in Assets}

Bargaining over the price of assets is a familiar prelude to exchange. For example, in a real estate transaction, a seller could state a price as part of the contract with his selling agent that the seller would then be bound to accept. The seller, however, prefers to list a selling price higher than the one he would in fact insist upon, and then to haggle with potential buyers over the actual transaction price. Although the seller of a painting lists his reservation price in the contract with his auctioneer-agent, the auctioneer neither opens nor (ordinarily) closes bidding at that price. Bargaining with prospective customers again determines who will own the asset, and how much will be paid if ownership is transferred. Rules that allow negotiation have evolved for art, real estate, and other assets. These rules are protected by law; a prospective buyer may not automatically obtain such assets simply by bidding first or even highest. The owner may rightfully refuse to sell.

In other words, owners of assets typically are protected by property rules rather than liability rules. ${ }^{7}$ Owners are therefore permit-

2 Calabresi \& Melamed, Property Rules, Liability Rules, and Inalienability: One View of the Cathedral, 85 Harv. L. Rev. 1089, 1092 (1972). Calabresi and Melamed define the two types of rules:

An entitlement is protected by a property rule to the extent that someone who wishes to remove the entitlement from the holder must buy it from him in a voluntary transaction in which the value of the entitlement is agreed upon by the seller. It is the form of entitlement which gives rise to the least amount of state intervention: once the original entitlement is decided upon, the state does not try to decide its value.

Id. at 1092. Once bargaining is abandoned, however, the state must intrude into the valuation process. As Calabresi and Melamed note:

Whenever someone may destroy the initial entitlement if he is willing to pay an objectively determined value for it, an entitlement is protected by a liability rule. This value may be what is thought the original holder of the entitlement would have sold it for. But the holder's complaint that he would have demanded more will not avail him once the objectively determined value is set. Obviously, liability rules involve an additional stage of state intervention: not only are entitlements protected, but their transfer or destruction is allowed on the basis of a value determined by Id. some organ of the state rather than by the parties themselves.

Although shareholders may refuse the tender offer, and consequently seem to have property protection for their shares, by using a two-tiered bid the bidder can create a prisoner's dilemma among shareholders. This makes it desirable individually for shareholders to 
ted to bargain over asset prices, rather than being forced to accept a price determined without interaction with the buyer. Contractual rules that countenance bargaining are found in almost all markets involving non-fungible goods or services. ${ }^{8}$ This raises a point of more general economic significance. Where markets are "thin" (i.e., where the number of potential purchasers is small and there is no preexisting market price at which reasonable quantities of the asset can be purchased), parties to any exchange typically bargain as bilateral monopolists to establish the price. Bargaining is costly, yet it dominates other rules for exchange in thin markets. Why, then, is bargaining the rule in virtually every thin market?

\section{A. The Role of Bargaining in a Theory of Property Rights}

Thick markets are characterized by frequent transactions of nearly homogeneous units. At any moment there is a "standard price quotation" for each of the traded items, which saves transaction costs. But items transacted in thin markets are not divisible or numerous enough to ensure that everyone values them equally at the margin. Because different persons value an item differently, they bargain whenever they attempt to trade.

It is possible to transact in thin markets without bargaining. If bargaining costs are high relative to the costs of other procedures for exchanging entitlements, an efficient legal system will dispense with property protection of entitlements, which endows traders with the bilateral vetoes necessary for bargaining to occur. Instead, transactions will be governed by liability protections, which enable one party to take an entitlement unilaterally. Compensation will be determined "objectively," or at least through a process not

tender at the price unilaterally selected by the bidder, even though the shareholders would all be better off if none tendered and the bidder were forced to bargain with the shareholders' agent, usually the firm's management. See Macey \& McChesney, A Theoretical Analysis of Corporate Greenmail, 95 Yale L.J. 13, 19-27 (1985). So if defensive tactics are impermissible, the prisoner's dilemma enables the bidder to convert property protection into liability protection.

s Examples of other markets that exhibit similar bargaining rules are plentiful. In purchasing new automobiles, customers frequently obtain bids from one dealer and use them to bargain for lower prices from other dealers. More ironically perhaps, managerial positions themselves (and academic positions, for that matter) are not offered on a take-itor-leave-it basis, but are subject to considerable bargaining about salary, perquisites, duties, and so forth, with bids from one prospective employer being used in negotiations with others. 
under the control of either party..$^{\circ}$ Ordinarily, liability remedies merely make whole the first party to lose his entitlement, meaning that all gains from trade go to the taker. ${ }^{10}$

By bargaining, each party tries to maximize his share of the gains from trade, net of bargaining costs. Bargaining consumes resources, and would be socially inefficient if it accomplished nothing but this short-run division of gains from any given trade. But in two distinct ways, bargaining is productive in the long run because it increases the magnitude of the gains to be partitioned. First, it assures that the traded items are worth more in other hands (i.e., that gains from trade exist). Liability rules cannot ensure the Pareto efficiency of exchanges because subjective values are hard to measure and so may not be fully compensated." Bargaining guarantees that no exchange occurs unless subjective values are recognized. This is an important function of bargaining, but it is not the focus here. Rather, this article focuses on the second role of bargaining, that of enhancing the subjective and objective values of the items to be exchanged.

At the moment of exchange, division of the gains is a zero-sum activity, without allocative consequences. But the ability to capture a greater portion of gains from trade tomorrow increases a party's incentive to augment the value of the asset today. ${ }^{12}$ Crea-

- Calabresi \& Melamed, supra note 7, at 1106-07.

10 See, e.g., Haddock \& Spiegel, Property Rules, Liability Rules, and Inalienability: One View of the Edgeworth Box, 1 Proc. Eur. A. L. \& Econ. 47 (1984); Oi, The Economics of Product Safety, 4 Bell J. Econ. 3 (1973); Rose-Ackerman, I'd Rather Be Liable Than You: A Note on Property Rules and Liability Rules, 6 Int'l Rev. L. \& Econ. 255 (1986); Veljanovski, The Employment and Safety Effects of Employers' Liability, 29 Scot. J. Pol. Econ. 256 (1982).

"See, e.g., Muris, Cost of Completion or Diminution in Market Value: The Relevance of Subjective Value, 12 J. Legal Stud. 379 (1983); Rea, Nonpecuniary Loss and Breach of Contract, 11 J. Legal Stud. 35 (1982).

13 This is a central paradigm in several strains of economic literature, particularly those analyzing alternative property rights. See, e.g., Demsetz, Toward a Theory of Property Rights, 57 Am. Econ. Rev. (Papers \& Proc.) 347 (1967); Gordon, The Economic Tbeory of a Common-Property Resource: The Fishery, 62 J. Pol. Econ. 124 (1954). For a summary of the empirical literature, see De Alessi, The Economics of Property Rights: A Review of the Evidence, 2 Res. L. \& Econ. 1 (1980). De Alessi summarizes in particular the link of concern here, that between ownersbip rewards and investment:

To tbe extent that resource rigbts are held in common, individual choices regarding tbe output to be produced, tbe production techniques to be used, the characteristics (amount, type, and time profile) of the investment to be undertaken as well as the time horizon and intensity of production will be affected . . . . Thus, since tbe indi- 
tion (and destruction) of an asset's value is a continuous process. The size of the gains to be divided in the current period is determined by the myriad investment and other decisions made by asset owners before coming to the bargaining table. Restricting a party's ability to negotiate will decrease the returns from his valueincreasing efforts, and will thus curtail such investments by him. The ability to bargain for an exchange is tantamount to a right to try to maximize the benefit of one's investments in an asset. ${ }^{13}$

\section{B. Value Creation by Target Firms}

Exchanges of blocks of corporate shares illustrate the role of bargaining in thin markets. When transacting relatively small numbers of a publicly traded corporation's shares, one deals in one of the thickest of markets. Hence, there is no bargaining, because by definition bargaining cannot alter relative prices in thick markets; there is no point to incurring bargaining costs if there are no benefits. Indeed, the buyer or seller rarely identifies his trading partner; every potential partner values the marginal share at the market price, so a partner's identity is irrelevant. But in the exchange of large blocks of shares, bargaining (with its concomitant costs) often occurs, suggesting that the block market is thinner, and that individual valuations differ at the margin. The market for controlling blocks is thinner still, and so costly bargaining is even more frequently observed. The market thins as a block of shares grows larger because a larger block confers greater ability to direct the corporation's belıvior, a power most investors cannot properly exploit, and tlius do not want.

Bargaining over blocks of shares allocates the gains from the transaction, and lias consequences for the initial creation of valu-

vidual lacks exclusive rights to the output of any investment he might make on the commonly owned resource, he has less incentive to invest this way.

Id. at 6 (footnote omitted). For recent recognition of this paradigm in the corporate takeover context, see Bebchuk, Comment: The Case for Facilitating Competing Tender Offers, 95 Harv. L. Rev. 1028, 1049 (1982) [hereinafter Competing Tender Offers]; Bebchuk, The Case for Facilitating Competing Tender Offers: A Reply and Extension, 35 Stan. L. Rev. 23, 42-43 (1982) [hereinafter Reply and Extension].

13 Bargaining costs thus resemble information costs. An individual's incentive to incur such costs arises solely from his interest in obtaining the best deal, with much of the gain at the expense of the trading partner. In the short run, the process largely results only in transfers hetween trading partners. But the long-run implications are important, because the process affects the future availability and value of the traded item. 
able assets. A no-resistance rule would diminish incentives to create corporate wealth in two ways. First, it would decrease whatever investments would otherwise be made in anticipation of realizing the returns through future exchange. Second, inability to resist a takeover would diminish certain types of specific investments, the returns from which hostile acquirers could expropriate.

\section{Wealth Creation Through Takeovers}

From the beginning, the theoretical takeover literature has focused almost exclusively on the value-increasing contributions of acquirers in ferreting out inept or dishonest management. ${ }^{14}$ Were all gains created this way, perhaps a no-resistance liability rule for protecting target firm entitlements would be appropriate; the rule would provide bidders with the maximum incentive to make valueincreasing investments by giving them, rather than targets, the largest feasible portion of the gains.

A no-resistance rule would be efficient, however, only if bidders created all the gains in takeovers, and targets none. If targets also make value-increasing investments, either at the time of a takeover or earlier, the desirability of mere liability protection depends on the elasticity of value creation by each side with respect to the rewards realized. The empirical literature is resolutely agnostic about the source of gains from takeovers. ${ }^{15}$ Given that this source may vary substantially from one transaction to another, ${ }^{16}$ compelling a no-resistance response seems unjustified.

Even adopting a short-run perspective of the takeover process, it is clear that bidders do not create all the gains. Firms do not always sit back and wait to be taken over. Some go looking for a bidder. ${ }^{17}$ Indeed, a manager can enhance his own position by

14 See, e.g., Manne, Mergers and the Market for Corporate Control, 73 J. Pol. Econ. 110 (1965).

${ }^{15}$ See, e.g., Jensen, Agency Costs of Free Cash Flow, Corporate Finance, and Takeovers, 76 Am. Econ. Rev. (Papers \& Proc.) 323, 328 (1986) (there are "approximately a dozen theories to explain takeovers, all of which I believe are of some relevance").

18 Jensen and Ruback note that "[v]arious sources of gains to takeovers have been advanced," but the studies showing gains from takeovers "cannot . . . distinguish between these alternative sources of gains." Jensen \& Ruback, The Market for Corporate Control: The Scientific Evidence, 11 J. Fin. Econ. 5, 23-24 (1983). They remark that it "would be surprising to find that all the gains . . . are due to a single phenomenon such as elimination of inefficient target management." Id. at 25.

17 When assets are unique, i.e., traded in thin markets, "sellers can also engage in search 
pointing out the undervalued nature of his firm to bidders, who will value his ability to discern such circumstances. When the firm is undervalued because assets should be reallocated out of the firm, insiders sometimes know this, and work toward an external remedy. By the same token, acquirers often do not actively search for targets, but merely hold themselves out as willing to entertain overtures from prospective targets. ${ }^{18}$ Targets would have little incentive to inform potential bidders of their undervalued shares if the bidders received most of the resulting gain. Finally, some firms specialize in matchmaking, i.e., in facilitating corporate pairing between two other firms. ${ }^{18}$ Matchmakers profit by taking a portion of the gains from the pairing.

In short, while corporate acquisitions require investments in search, it is not just bidders who invest. There is no reason, then, to award all the gains from trade to bidders. If different parties can create value in the asset being transferred, the optimal rule would create incentives for all to increase value until the marginal return to each equaled its marginal opportunity cost.

Adopting a longer-run perspective, the importance of the target firm's own investments is even greater. The opportunity arises every day for a firm to make value-creating investments, the full

. . . in the literal fashion that buyers do." Stigler, The Economics of Information, $69 \mathrm{~J}$. Pol. Econ. 213, 216 (1961), reprinted in G. Stigler, The Organization of Industry 171, 175 (1968). For mention of this point in the takeover context, see Competing Tender Offers, supra note 12, at 1049; Reply and Extension, supra note 12, at 38-39. The search cost a party will undertake is a positive function of the expected reward. This is a fundamental aspect of the economics of information. See Stigler, supra, at 219 , reprinted in G. Stigler, supra, at 180 ; G. Stigler, The Theory of Price 1-4 (3d ed. 1966); Bebchuk, Toward Undistorted Choice and Equal Treatment in Corporate Takeovers, 98 Harv. L. Rev. 1693, 1776 (1985) [hereinafter Undistorted Choice]; Mortensen, Property Rights and Efficiency in Mating, Racing, and Related Games, 72 Am. Econ. Rev. 968 (1982).

${ }^{18}$ The following advertisement ran last year in the Wall Street Journal: "Acquisitions Wanted. Ocilla Industries, Inc., a publicly traded OTC-National company with a significant cash position, is seeking acquisitions meeting the following criteria . . . Brokers' inquiries welcome and brokers will be fully protected. Please call or write . . . "Wall St. J., May 27, 1986 , at 62 , col. 4 .

${ }^{10}$ See, e.g., Petre, Merger Fees That Bend the Mind, Fortune, Jan. 20, 1986, at 18, 21 (investment bankers increasingly involved in acquisitions because they "devise clever stratagems and think up new kinds of transactions"); Sterngold, Wall Street's Army of Insiders, N.Y. Times, May 18, 1986, at F1, F8, col. 4 ("Merger teams originate many deals on their own today, rather than waiting for a client to ask for help, because they need a constant flow of transactions to keep the large staffs profitably employed."); Gupta, Intermediaries Play a Bigger Role in the Venture Business, Wall St. J., Sept. 11, 1986, at 1, col. 5 (matchmakers and advisors "wield increasing power"). 
returns from which may only be realized through a possible future takeover. Firms sometimes can create value by making initial investments that others are better able to develop, and so plan from the start to be acquired by another. For example, many computer software companies plan to be taken over if they successfully innovate even one important software package. This expectation enables them to concentrate on technical innovation and to ignore subsequent marketing, which is of no value until a technical advance has been completed. Much small-scale research in other fields follows a similar pattern. ${ }^{20}$ The same process typifies both large-scale and personal real estate investments; property owners hesitate to make improvements unless they can "get their money out" when they sell. ${ }^{21}$

In other words, takeovers are not discrete events that begin at the moment the first bid materializes. All firms are "in play" from the day they are created, and the possibility of a later takeover only spurs greater innovation now. The more attractive the posttakeover asset configuration foreseen, the more effective the spur.

Forming a new company with the intention of being taken over is like planning to "go public" once the success of the company is manifest. Both techniques permit financing of untested projects by an entrepreneur adept at judging projects' potential, while freeing him from post-innovation management, a duty for which he may be poorly qualified. In other words, "inept" management may result from high opportunity costs, rather than from some moral failing or incompetence. That many fledgling companies anticipate the likelihood of going public is clear from contracts signed when the company is formed specifying who will pay the costs of the initial public offering.

Even entrepreneurs who do not intend their firms to become targets nevertheless foresee some probability that their firms will fail to achieve their principal goals. The potential for being acquired or for selling off assets provides insurance against such an event. $^{22}$ If the insurance payoff were reduced by a shift from prop-

20 One group puts together new Ph.D.'s to create new research firms, then sells the firms to pharmaceutical companies. Boland, A Lot of Happy People, Fin. World, May 13, 1986, at 108.

"For example, real estate ventures often issue prospectuses stating as their "investment objectives" the acquisition, holding, and ultimate disposal of various real estate properties.

22 The insurance function of subsequent acquisitions and sales is seen in the movie and 
erty to liability protection, some risky ventures would never be initiated. Additionally, reduced rewards from secondary asset uses would shift the form of initial investments. Those ventures still undertaken after the takeover "insurance" payoffs were reduced would be investments in assets more highly specialized to their primary objective, and hence less suited to uses elsewhere. ${ }^{23}$

\section{Protecting Existing Quasi-Rents of Human Capital}

Aside from increasing targets' shares of the gains from trade, there is another way that bargaining (resistance) increases investments in potential targets. Bargaining makes takeovers less likely in cases where there are no gains, only transfers, at stake.

In their daily operations, firms face two types of risk, systematic and firm-specific. Coping with each type of risk requires different managerial skills. Adapting to systematic risk requires generalized skills readily marketable elsewhere. But, as Demsetz and Lehn have explained, firm-specific variations require investments in firm-specific human capital that are not readily transferable. ${ }^{24}$ In-

television business. Frequently, moviemakers and investors organize to make a picture, intending to sell the product to a distributor. See Nulty, New World's Boffo B Movie Script, Fortune, Feb. 17, 1986, at 48 (New World Pictures banking on the profitability of the home video market for " $B$ " movies). If the distributor fails to make money in the theaters, he will pull the film back and sell it instead for use in the home video market. Id. at 50. Similarly, most television series produced for prime time fail to make money there. But it is increasingly possible to resell them for syndicated rerun in order to reduce losses, or even to make money, on the venture. See Sherman, A TV Titan Wagers a Wad on Movies, Fortune, May 12, 1986, at 40 (Telepictures able to syndicate Eugene Ionesco's play Rhinoceros-"outright junk by TV standards").

In general, the process of reclaiming failed ventures, managing them back to profitability, and then selling them off has become highly specialized. Practitioners are known as "turnaround venture capitalists," or "vulture capitalists." See Stevens, Lots of Business, Fin. World, June 10, 1986, at 32.

${ }^{23}$ Holding all else equal, an owner clearly will prefer to make investments that maximize returns if the firm's experience turns out as the owner expects. But just as clearly, again holding all else equal, the owner will prefer investments that are adaptable, in case the firm's experience turns out other than expected. It follows that an investment that simultaneously offers greater returns and greater adaptability will always be preferred to an investment offering less of each. Consequently, the entrepeneur will have to make hard choices only among alternatives with the following attributes: the less adaptable options will have to offer higher returns to be attractive, which is to say, the more adaptable investments will offer lower returns. If the advantages of adaptability are curtailed (through a no-resistance rule, for example), entrepreneurs will shift investments on the margin toward those with higher expected returns but lower adaptability.

${ }^{24}$ See Demsetz, Corporate Control, Insider Trading, and Rates of Return, 76 Am. Econ. 
dividuals will make such investments only if the expected rewards exceed their best alternative by enough to provide a normal return.

Yet investments that are specific to assets owned by others place the investor at risk from those others' opportunistic behavior. ${ }^{25}$ As long as the individual realizes at least as much as can be had in the best alternative, the invested human capital will remain, even if the returns are expropriated. The best alternative, of course, offers no premium for the firm-specific investment. Long-term guarantees may control the potential for opportunism by one party, but contracts that guarantee the other party's income invite shirking, i.e., opportunism by that party. ${ }^{2 B}$

Rev. (Papers \& Proc.) 313, 315 (1986); Demsetz, The Structure of Ownership and the Theory of the Firm, 26 J.L. \& Econ. 375 (1983) [hereinafter Structure of Ownership]; Demsetz \& Lehn, The Structure of Corporate Ownership: Causes and Consequences, $93 \mathrm{~J}$. Pol. Econ. 1155 (1985).

${ }^{25}$ See Alchian, Decision Sharing and Expropriable Specific Quasi-Rents: A Theory of First National Maintenance Corporation v. NLRB, 1 Sup. Ct. Econ. Rev. 235, 238-40 (1982); Klein, Crawford \& Alchian, Vertical Integration, Appropriable Rents, and the Competitive Contracting Process, 21 J.L. \& Econ. 297, 313 (1978).

26 If there is no danger that the trained employee will quit, initial investment in specific human capital will be borne entirely by the firm through wage rates in excess of realized marginal products during an initial training period. See G. Becker, Human Capital 18-29 (1964). After the investments have been completed, the firm reaps a return by paying wages equal to those available elsewhere, which are below the employee's (now enhanced) marginal product within the firm to which his human capital is specific.

If the turnover rate is not zero, however, the situation is different:

If a firm had paid for the specific training of a worker who quit to take another job, its capital expenditure would be partly wasted, for no further return could be collected. Likewise, a worker fired after he had paid for specific training would be unable to collect any further return and would also suffer a capital loss. The willingness of workers or firms to pay for specific training should, therefore, closely depend on the likelihood of labor turnover.

Id. at 21. Becker notes that the likelihood of a quit is not fixed; because it depends on wages, a firm contemplating specific human capital investments in its employees might "offer employees some of the return from training. Matters would be improved in some respects but worsened in others, for the higher wage would make the supply of trainees greater than the demand, and rationing would be required." Id. at 22. Moreover, the magnitude of investment would not be pursued to the proper margin.

The final step would be to shift some training costs as well as returns to employees, thereby bringing supply more in line with demand. When the final step is completed, firms no longer pay all training costs nor do they collect all the returns but they share both with employees. The shares of each depend on the relations between quit rates and wages, layoff rates and profits, and on other factors not discussed here.

Id. (footnote omitted).

The firm-specific human capital embodied in a firm's top executives often is unique. At any given moment particular executives will be uniquely qualified to perform particular managerial tasks for the firm. The situation is akin to a bilateral monopoly, and an execu- 
Consequently, those making firm-specific human capital investments sometimes defend against potential opportunism by taking control of the asset to which their investment is specific. ${ }^{27}$ In the corporate context, those who specialize for the benefit of the firm often acquire a substantial block of shares in that firm. This implies a higher concentration of shareholding in firms benefiting from more firm-specific human capital, a prediction confirmed empirically. ${ }^{28}$

In effect, not all shares are equal. Controlling shareholders will divert greater rewards per share to themselves than to other shareholders. This is not thievery, but part of an implicit contract to induce investments in firm-specific human capital of general benefit to the firm and hence to all shareholders. The thick public market in shares will be populated only by "ordinary" shareholders, while controlling shareholders will sell their larger blocks more rarely and only for a higher price. ${ }^{28}$ The daily "market price"

tive's well-timed strategic threat to withhold his services can leave the firm in an extremely poor bargaining posture. Consequently, in such instances the interests of shareholders will require that the executive's rewards approximate his marginal product, including the marginal product of his firm-specific human capital. In that way the executive himself will bear the full cost of a withdrawal of his services.

But this analysis implies that there is no payoff to the firm for prior investment in firmspecific capital uniquely embodied in executives. If the initial investment is to be made, it must be made entirely by the executive; but, symmetrically, that leaves the executive at risk of expropriation of the returns to his investment, should the firm begin to bargain strategically.

${ }^{27}$ This taking of control resembles vertical integration, which is one mechanism identified by Klein, Crawford \& Alchian, supra note 25 , at 299, for controlling opportunism. Of course, ownership of shares is not the only device available to managers to mitigate the risk of expropriation. Pension rights, golden parachutes, severance pay, and the like, all raise the cost to the firm of carrying out an opportunistic threat. But to say there are alternatives does not mean that they are perfect substitutes for all firms in all situations. That, in turn, means that depriving managers of the ability to make and protect investments in blocks of shares must increase the overall cost of managerial services.

28 Demsetz \& Lehn, supra note 24, at 1158-60. In Structure of Ownership, supra note 24, at 388, Demsetz finds that managers and directors do indeed own substantial blocks of the employing firm's shares (usually $20 \%$ or more), except in the very largest corporations.

There is a link between controlling managerial malfeasance (upon which the takeover literature concentrates) and controlling passive shareholder opportunism. For both reasons, shares of firms that are relatively difficult to control are worth more to controlling shareholder-managers than to passive investors, and so one expects a high degree of integration of management and shareholding in those firms. See Alchian \& Demsetz, Production, Information Costs, and Economic Organization, 62 Am. Econ. Rev. 777, 785-86 (1972).

${ }^{20}$ The divergence of a block's value from the product of quoted share price times the shares in the block is constrained by the transaction costs of assembling or dispersing a 
quoted on the telex is lower than the reservation value that controlling shareholders place on the shares in their blocks, because the price at which they will sell includes a premium, the size of which must be determined through bargaining. ${ }^{30}$

Yet each share typically has the same voting power. If establishing property rights were costless, those shareholders with more at stake would also have a more potent voice. Larger individual holdings in any firm imply the higher costs of diminished portfolio diversification; ${ }^{31}$ controlling shareholders still might own only a minority of the voting potential. Hence, "controlling" shareholders are usually only semi-controlling. But the free-rider situation created by widely dispersed share ownership normally affords (semi-) controlling shareholders sufficient protection from human capital expropriation by fellow shareholders.

This opens an avenue through which an outside bidder (for once, the term "raider" is appropriate) can profit. If defensive tactics are barred, a hostile bidder can overcome the free-rider problem among incumbent shareholders and expropriate the full value of

block of similar size piecemeal. Even if there are enough shares held outside blocks to enable one to assemble a block of specified size, assembling a block will not be a perfect substitute for purchasing one. For example, the concentration of voting power will differ. Moreover, block assembly requires more interaction with the market than does block purchase, and thus assembly increases the number of third parties "tipped" about one's activities.

so In some cases, a minor divergence of interests among shareholders may be usefully reconciled through resort to a "single owner" analogy. See, e.g., Undistorted Choice, supra note 17 , at 1764-80. This is particularly true when shareholders have similar interests ex ante, but free-rider and hold-out problems create disputes ex post. See Grossman \& Hart, Takeover Bids, the Free-Rider Problem, and the Theory of the Corporation, 11 Bell J. Econ. 42 (1980). When there are fundamental differences among shareholder interests ex ante, however (as there are in the instance considered here), there is no logical way to amalgamate divergent interests into a conceptual "sole owner." Cf. K. Arrow, Social Choice and Individual Values (2d ed. 1963) (discussing inherent failings of standard majoritarian voting processes).

31 Acquiring control of one of the few largest corporations in tbe economy requires a nondiversified investment of impressive size, with daunting cost to the risk-averse. Although there are exceptions, Demsetz has shown that the stock interest of management in very large corporations tends to be low, averaging $2-3 \%$, compared with smaller companies, where managers and directors typically hold $20-30 \%$ of their corporations' voting shares. See Structure of Ownership, supra note 24, at 388.

If, in the face of their more tenuous, minority voting control, managers of a giant corporation are to make value-increasing investments in firm-specific human capital, they must have greater latitude to resist hostile takeovers than managers holding controlling interests; otherwise, they cannot protect their quasi-rents from expropriation. When the relative cost of alternative tools differs between situations, the optimal mix of tools will differ also. 
controlling shareholders' firm-specific investments. The situation is similar to an eminent domain taking, where asset owners are paid only the "objective" or market value of what is taken. Owners who attach a higher subjective value to the asset taken will not be paid full value. Property-rule protection of the asset, forcing would-be takers to negotiate with owners, would guarantee that full compensation was paid. A liability rule permits the taker (the government in an eminent domain proceeding, the "raider" in a takeover) to acquire property for less than full value. ${ }^{32}$

Controlling shareholders can limit this risk by including provisions in the corporate charter or bylaws permitting resistance to hostile takeovers. In effect, they will minimize the overall cost of potential quasi-rent expropriation by mixing (costly) diversification-reducing but control-increasing tools with (also costly) takeover-resisting measures. This mix is beneficial to all shareholders because it induces appropriate investments in firm-specific capital in the first place. ${ }^{3 s}$

The interests of controlling shareholders, who own large percentages of residual claims, are highly correlated with the interests of other shareholders and hence of the firm as a whole. To the extent that the correlation is not perfect, noncontrolling shareholders discount the price they pay for shares initially. To restrain that discount when seeking original or additional capital, controlling shareholders have an incentive to deny themselves any ability to resist takeovers not beneficial to the firm as a whole. Through the lower initial share price, the noncontrolling shareholders are compensated for any remaining costs of permitted resistance.

Other situations may present similar opportunities for "raiders."

${ }^{32}$ See R. Epstein, Takings: Private Property and the Power of Eminent Domain 216-18 (1985); see also Munch, An Economic Analysis of Eminent Domain, $84 \mathrm{~J}$. Pol. Econ. 473 (1976) (eminent domain is not, in fact, more efficient than the free market for consolidating many separately owmed parcels of land into a single unit).

${ }^{33}$ This notion of expropriation of managerial quasi-rents is similar to that analyzed by Knoeber. See Knoeber, Golden Parachutes, Shark Repellants, and Hostile Tender Offers, 76 Am. Econ. Rev. 155, 158-59 (1986). However, Knoeber focuses on potential expropriation of managerial compensation that has been deferred until better information on performance becomes available. Id. at 159 . Deferral of compensation for past services creates a risk that payment will not be made in the event of a hostile takeover. Id. at 159-60. At this point, our article focuses instead on firm-specific investments, the returns from which are to be realized in subsequent periods, and which are thus subject to similar opportunism in the event of a takeover. 
In addition to quasi-rents from human capital, returns to other valuable assets may be expropriable. Suppose that management has discovered changes in firm structure or activities that will enhance the value of the firm, but has not made the information public. An outside bidder who discovers that information could acquire shares from shareholders who are ignorant of the changes. To limit losses to an outside bidder, shareholders would want management to resist any takeover until the changes have been effectuated and the shares have risen in price. ${ }^{34}$

There is an unwarranted presumption in much of the takeover literature that outside entrepreneurs employed by bidding firms can know something important that the market does not, but that inside entrepreneurs employed by a target cannot. ${ }^{35}$ If that were true, there would be no insider trading. But whenever firms invest in valuable information that cannot be made public, an opportunity exists for an outsider who learns of the information. In that case, shareholders will want management to protect their returns from information for which they have paid.

\section{Search Rates for Targets}

The issue of appropriate property rights in target firms' shares can be approached from another perspective. The search for undervalued targets, like the search for new ideas, is costly. When

\footnotetext{
st This hypothetical setting parallels an actual episode. Prior to the recent threat by Sir James Goldsmith to acquire control of Goodyear Tire \& Rubber Company, Goodyear had hired two investment banking firms to study possible restructuring of Goodyear. Restructuring was recommended, but the information was to be kept private. Before Goodyear could act on the restructuring recommendations, however, Goldsmith acquired a substantial minority stake in Goodyear. The stake was interpreted as preliminary to a takeover bid, after which Goldsmith would himself have restructured the company. There is no evidence that Goldsmith was privy to any inside information. See Winter \& Stricharchuk, Goodyear, Responding to Takeover Bid, Seeks Buyer for Its Oil and Gas Unit, Wall St. J., Nov. 4, 1986, at 3, col. 2. Goldsmith said that the company's restructuring plans were largely the same as his. Stewart \& Revzin, Sir James Goldsmith, As Enigmatic as Ever, Bails Out of Goodyear, Wall St. J., Nov. 21, 1986, at 1, col. 6. Partly because the prospects of Goldsmith's restructuring were becoming dimmer, Goldsmith eventually agreed to resell his shares at a premium to the firm, which then proceeded with its prior restructuring plans. Stricharchuk \& Stewart, Goodyear Tire To Buy Interest from Sir James, Wall St. J., Nov. 21,1986 , at 3 , col. 1 .

s5 Cf. Easterbrook \& Fischel, Corporate Control Transactions, 91 Yale L.J. 698, 705 (1982) (describing potential gains from control transactions, but attributing none to incumbent management).
} 
several different claimants to a profitable idea or asset emerge, some scheme for allocating the property right must also emerge. One possible scheme is first come, first served.

Various authors have shown, however, that establishing property rights by first possession ordinarily results in premature capture. ${ }^{36}$ Moving resources to higher-valued uses as fast as possible is undesirable. Speed is costly. Rapid search consumes more resources per unit of discovery than does leisurely search. ${ }^{37}$ Hence, attempting maximum speed in replacing poor management, or reallocating corporate resources for any other reason, is ill-advised. Finding better managers too soon makes them too expensive; found too soon, management is only "better" in an engineering, not an economic, sense.

The search for targets consumes resources which have valuable alternative uses. Resources will be diverted too soon if title to the entire increase in a corporation's value arising from reallocating control can be established only by racing to the firm before a competitor reaches it. Well-defined property rights control the race by forcing contenders to deal with an owner or agent capable of implementing an internally consistent plan of action. ${ }^{38}$ Weakening their property rights by removing shareholders' ability to bargain would open a "common," to be claimed by the first arrival. ${ }^{39}$ Fac-

${ }^{38}$ Barzel, Optimal Timing of Innovations, 50 Rev. Econ. \& Stats. 348 (1968); Dasgupta \& Stiglitz, Uncertainty, Industrial Structure, and the Speed of R \& D, 11 Bell J. Econ. 1, 25-26 (1980); Mortensen, supra note 17, at 969-70. To use Mortensen's terminology, hostile takeovers have some of the aspects of an "innovation race" and some aspects of a "mating game." Id. at 969-75. Only if takeovers were purely a mating game, and only if bidders were the only parties searching, would a no-resistance rule he desirable. Id. at 973 . One crucial assumption of Mortensen's mating game is that the success of a party of one type (such as targets) does not affect the distribution of complementary types available to be found. Id. at 976. This assumption does not accurately represent matters in the market for corporate control. For a generalized application of the Barzel-Dasgupta/Stiglitz-Mortensen analysis to examples extending beyond property rights in research and development, see Haddock, First Possession Versus Optimal Timing: Limiting the Dissipation of Economic Value, 64 Wash. U.L.Q. 775 (1986). For an analysis of one historical instance in which first-come-firstserved property rights proved inefficient, see McChesney, Government Prohibitions on Volunteer Fire Fighting in Nineteenth-Century America: A Property Rights Perspective, $15 \mathrm{~J}$. Legal Stud. 69 (1986).

${ }^{37}$ Alchian, Costs and Outputs, in The Allocation of Economic Resources 23, 25 (1959); see Alchian, Reliability of Progress Curves in Airframe Production, 31 Econometrica 679 (1963).

${ }^{38}$ See R. Posner, Economic Analysis of Law 33-39 (3d ed. 1986); Kitch, The Nature and Function of the Patent System, 20 J.L. \& Econ. 265, 276 (1977).

${ }^{30}$ See Hardin, The Tragedy of the Commons, 162 Science 1243, 1244-45 (1968). The 
ing no resistance, first bidders would be more likely to be the only bidders, since no defense could be used to elicit competing bids.

\section{Externalities from Managerial Resistance to Tender OFFERS}

The preceding Part illustrated various ways in which the ability to bargain is advantageous when assets, including blocks of corporate shares, are traded in thin markets. Bargaining awards a greater share of the gains from trade to the seller, and is a desirable practice whenever sellers are at least partially responsible for searching out exchange partners. More importantly, the ability to bargain gives the owners of assets greater incentives to enhance the assets' value prior to an exchange. It also facilitates the defeat of those takeover bids that represent not value-maximizing exchanges, but only transfers from those who make valuable firmspecific investments. Because those individuals value the firm's existing configuration more highly than do a majority of shareholders, these individuals' inability to bargain for a better deal would discourage their firm-specific investments in the first place.

These advantages explain why bargaining is the norm in most thin markets, and why the law typically does not impose liability rules there that would prevent negotiation. Nevertheless, Easterbrook and Fischel have argued that the courts or legislatures should prohibit managerial bargaining over takeovers by banning managerial resistance to takeover bids. ${ }^{40}$ The Easterbrook-Fischel model is well known, and needs little summary here. In effect, it argues, the market for corporate control is different from other markets for two reasons.

First, the expectation of a target firm's resistance acts as a disincentive to bidders, who therefore monitor all firms in the market less. ${ }^{41}$ Reduced monitoring by bidders means that other firms pay

\footnotetext{
"commons" effect can occur when common users of a given asset do not individually register marginal costs as the asset is depleted; thus, they overuse the asset to the point of exhaustion. The phenomenon draws its name from the overgrazing that typically took place on public commons. But see Gordon, supra note 12 (if the rate of exploitation of an asset is decreased, as is appropriate in a commons, but no other aspect of the right to the asset is established, the cost of exploitation is increased until, at the margin, the entire value of the resource is dissipated).

${ }^{10}$ Proper Role, supre note 2, at 1180-82; Auctions, supra note 2, at 21.

4 Proper Role, supra note 2, at 1176-77.
} 
for the target's resistance, creating an externality that allegedly requires a legal no-resistance rule for correction. This externality would arise even if target shareholders themselves, acting in their own interest, resisted takeover bids. But typically it is management that resists in the name of its shareholders. This, Easterbrook and Fischel claim, makes resistance undesirable for a second reason: managers resist not only when resistance benefits their shareholders, but also when it wrongfully safeguards management jobs. ${ }^{42}$ Thus, resistance not only creates externalities costly to other firms, but increases managerial agency costs to the target itself.

This Part, and the next two, considers both these objections to bargaining over corporate assets. Neither externalities nor excessive agency costs necessarily accompany takeover resistance. Furthermore, even if externalities and agency costs were substantial problems, they would not necessarily justify a legal ban on bargaining. The ability to bargain still has the value-enhancing advantages discussed in Part I. Even if these externality and agency cost problems exist, therefore, whether they justify a no-resistance rule is an empirical question; if the benefits of bargaining exceed the externality and agency costs, there is no good reason to ban resistance.

\section{A. The Externality Problem}

Easterbrook and Fischel argue that the application of a common-law business judgment rule to condone resistance would be wrong, even when resistance would benefit target shareholders. ${ }^{43}$ Empirical evidence shows that, on average, tender offers benefit target firm shareholders ex post. ${ }^{44}$ But the possibility of resistance results in some bids being foiled ex ante, with shareholders thus losing the takeover premiums. Moreover, Easterbrook and Fischel claim that "[e]ven resistance that ultimately elicits a higher bid is socially wasteful."45

\footnotetext{
42 Id. at 1175.

43 Id. at 1195 (business judgment rule "should never serve to justify a decision to oppose a tender offer").

14 The empirical evidence indicates that target firm shareholders receive, on average, a $29 \%$ premium from a successful tender offer. See Jensen \& Ruback, supra note 16, at 10-13. The returns to successful bidders are much smaller, averaging only ahout 4\%. Id. at 16-17.

45 Proper Role, supra note 2, at 1175.
} 
There are two sources of alleged waste. First, the target firm's resistance consumes resources, while the gains from resistance are asserted to be merely transfers from bidding firms, rather than the creation of new wealth. This is just a bargaining cost, however, neither more nor less troublesome in the takeover context than in any other thin market. Second, and more importantly, resistance by the target firm imposes an external cost on other firms, the managers of which are monitored less by potential takeover bidders:

[The] "externality" arises when a target's management resists a tender offer. The resulting increase in the prices paid for target firms will generally discourage prospective bidders for other targets; when the price of anything goes up, the quantity demanded falls. Changes in the incentives of bidders affect the utility of monitoring by outsiders, and that affects the size of [other firms' managerial] agency costs and in turn the pre-offer price of potential targets' stock. ${ }^{46}$

In other words, the externality arises because resistance by one target reduces the returns of monitoring by prospective bidders, and thus "there is too little monitoring and investors' wealth falls."47 To end the perceived externality, Easterbrook and Fischel advocate legal intervention to prohibit a target firm's management from using any defensive tactics. ${ }^{48}$

The legal community has resisted the proposed no-resistance rule. Courts refuse to apply it ${ }^{49}$ and commentators disagree with

46 Id. at 1176-77.

47 Auctions, supra note 2 , at 6 .

is Not all defensive tactics fit the Easterbrook-Fischel paradigm. Greenmail paid to prospective bidders, for example, has only trivial resource costs and can increase, not decrease, the amount of monitoring bidders do. Macey \& McChesney, supra note 7 at 38-43.

40 See, e.g., Unocal Corp. v. Mesa Petroleum Co., 493 A.2d 946 (Del. 1985). Citing Easterbrook and Fischel, the Delaware Supreme Court noted that "[i]t has been suggested that a board's response to a takeover threat sbould be a passive one. . . . [But] as the proponents of this rule of passivity readily concede, it has not been adopted either by courts or state legislatures." Id. at 955 n.10; see also Revlon, Inc. v. MacAndrews \& Forbes Holdings, Inc., 506 A.2d 173, 180 (Del. 1986) (board of directors had the power to adopt a "poison pill" defense in response to a hostile takeover bid); Moran v. Household Int'l, Inc., 500 A.2d 1346, 1357 (Del. 1985) (directors adopting poison pill defense in anticipation of a possible takeover attempt protected by business judgment rule).

In a lengthy discussion of Easterbrook and Fischel's analysis, Judge Posner stated that "[p]ersonally we are rather skeptical about the arguments for defensive measures." Dynamics Corp. of Am. v. CTS Corp., 794 F.2d 250, 255 (7th Cir. 1986), rev'd, 55 U.S.L.W. 4478 
portions of the analysis. ${ }^{50}$ For example, it has been noted that although resistance consumes real resources, resistance also avoids the transaction costs of subsequent transfers if the first bidder is not the highest-valuing user of the target firm's resources. ${ }^{51}$ The debate has also focused on elasticities, i.e., on just how many bids are lost because firms can resist..$^{\mathbf{2}}$ On the more fundamental externality point, however, there has been only acquiescence with the Easterbrook and Fischel model. ${ }^{53}$

(U.S. Apr. 21, 1987) (Nos. 86-71, 86-97). But the Seventh Circuit refused in that case to rule the target company's poison pill plan invalid per se, despite "grave doubts" about defensive measures, because the court was construing Delaware law. Id. The court recognized that "Delaware courts have been quite emphatic that defensive measures in general . . . are within the power of the board of directors of a target corporation." Id. at 256.

so See, e.g., Competing Tender Offers, supra note 12, at 1029-30; Gilson, Seeking Competitive Bids Versus Pure Passivity in Tender Offer Defense, 35 Stan. L. Rev. 51,66 (1982); Oesterle, Target Managers as Negotiating Agents for Target Shareholders in Tender Offers: A Reply to the Passivity Thesis, 71 Cornell L. Rev. 53, 55-56 (1985).

${ }^{51}$ In other words, the real resource costs of resistance may be offset by savings in the transaction costs of subsequent serial transfers. See Competing Tender Offers, supra note 12, at 1048-49. Easterbrook and Fischel suspect the reverse, that auction costs exceed the costs of successive transfers. Auctions, supra note 2 , at 14 . The issue is solely empirical, but neither side has presented any data to support its position.

${ }^{52}$ The elasticity debate has centered on the size of bidders' sunk costs, that is, on the extent to which costs can be recouped in the event bidders are thwarted by managerial resistance. The crux of the inquiry is, therefore, the overall effect of resistance on reducing bidders' search efforts. See, e.g., Reply and Extension, supra note 12, at 30 (conceding that allowing managerial resistance reduces bidders' search, but arguing that the reduction "is unlikely to be substantial"). Again, no data are offered to support the claim that elasticities are low, so the empirical claim cannot be evaluated. But the Easterbrook and Fischel model does not depend on the size of the supposed externality; as long as there is any, it claims, too little monitoring and bidding will result. Auctions, supra note 2 , at 7.

ss See, e.g., Jarrell, The Wealth Effects of Litigation by Targets: Do Interests Diverge in a Merge?, 28 J.L. \& Econ. 151, 151-54 (1985). Jarrell finds that when target firms resist initial tender offers by litigating against the bidder, the expected gains from higher subsequent bids outweigh the costs of both the litigation and the risk that no subsequent offer will materialize. Id. at 174-75. Defensive tactics, Jarrell initially suggests, may seem to be "sensible gambles, rather than shameful self-dealing by managers." Id. at 175. But Jarrell ultimately concludes that resistance is nevertheless welfare-reducing:

[T]his conclusion-that litigious defenses can be beneficial to target shareholders-does not imply that such actions enhance social welfare. Indeed, the opposite is more likely to be true, because litigious defenses redistribute some of the gains from corporate combinations from acquirers to the targets. This redistribution is analogous to a tax on acquirers.

Id. But the redistribution is not analogous to a tax, because it does not simply disappear into an uninvolved treasury. It is received by the other party to the transaction, someone capable of reacting appropriately to the implied opportunity cost. See Coase, The Problem of Social Cost, 3 J.L. \& Econ. 1, 39-42 (1960). 


\section{B. Relevant vs. Irrelevant Externalities}

"Externality" is a slippery concept, one less often used to elucidate a supposed "problem" than to justify government intervention to "solve" it. ${ }^{54}$ The efficiency issue is not whether any third-party impact takes place-that is inevitable-but whether the appropriate marginal conditions still hold. Many externalities are solely pecuniary; they change prices but do not raise efficiency concerns as long as prices still equal marginal cost..5 $\mathrm{A}$ problem arises only when prices and costs diverge, creating a non-pecuniary (or "technological") externality.

There are really two distinct externalities connected with resisting takeovers in the Easterbrook and Fischel model, although the model does not distinguish them. The first, fewer bids for targets, is merely pecuniary. This allegedly undesirable effect of resistance comes about because of the "resulting increase in the prices paid for target firms," meaning that "the quantity demanded falls." ${ }^{\text {"B }}$ Bidders are aware of the possibility-indeed, the virtual certainty - that their first bid will not be accepted, and at the margin adjust the amount of search and bidding they undertake to reflect the higher price of takeovers. Resources will be used differently, but no inefficiency arises. The pecuniary externality is real enough, but does not justify legal intervention on efficiency grounds.

The second externality arises because bidders adjust monitoring of potential target firms as takeover premiums rise. This externality admittedly is non-pecuniary, but that is not the end of the analysis. Five conditions still must be met before the legal system should intervene to correct even a non-pecuniary externality. ${ }^{.7}$ First, the actions of one party must affect other parties who have

s. Cf. E. Mishan, Cost-Benefit Analysis 107 n.5 (1971) ("There are quite a number of economic phenomena... masquerading in the literature as external effects which cannot be admitted [as sucb].").

ss Id. at 103-05. Changes in prices "will lead to changes in the equilibrium output of goods and services, but each equilihrium will be equally efficient, or Pareto optimal." J. Due \& A. Friedlaender, Government Finance: Economics of the Public Sector 80-81 (5th ed. 1973).

se Proper Role, supra note 2, at 1176-77; see supra note 46 and accompanying text.

${ }^{87}$ If the actors in the legal system, such as the legislature, are themselves self-interested, these five conditions, while still necessary, will not be sufficient to assure the desirability of legal intervention. 
little or no influence over the decisions of the first party. ${ }^{58}$ Second, the impact on the affected parties must alter their behavior. ${ }^{59}$ Easterbrook and Fischel imply that these first two conditions for legal intervention are met, which is concededly plausible.

But these two necessary conditions are not sufficient to justify intervention that would reduce the level of an activity. An externality must also be an external cost, meaning that the affected parties would want the level of that cost-generating activity reduced. ${ }^{60}$ In the corporate context, it is unclear whether third-party targets would want less takeover resistance, because it is unclear whether resistance results in a net cost to them. Only if resistance results in a net cost to targets would they want less of it. True, resistance decreases gains of bidders at the moment of takeover, which reduces bidder search for a given level of corporate investment. But as Part I noted, in the more dynamic market setting an ability to resist enhances target gains from a successful takeover and thus increases the amount of investment in place at any moment. This, in turn, makes a larger number of firms attractive targets. All else being equal, the increased population of potential targets increases bidder incentive to search by raising the likelihood that a bidder can locate a target of sufficient attraction. ${ }^{61}$

There is no apparent reason to believe that the first impact dominates the second, or vice versa. The issue is empirical. If the first impact, reduced bidder search, dominates, the externality is indeed an external cost, and shareholders in potential targets will want the resistance of other targets weakened. But if the second

s8 Buchanan \& Stubblebine, supra note 6, at 372 .

so See id. at 373-74. More technically, the externality must be marginal rather than inframarginal if this second condition is to be met. Id. at 374 .

${ }^{B 0}$ Id. Because the desire of one party to alter the other's behavior is only one of several conditions that must be met if legal intervention is to be justified, Buchanan and Stubblebine refer to externalities satisfying this particular criterion as only "potentially relevant." Id. at 373.

${ }^{61}$ An example underlines the point. A person is not required to accept the first marriage proposal received. One may spurn the first (or $n$ th) suitor, even though that creates a risk of never getting a better offer. But the amount of search for spouses does not necessarily fall when such discretion is tolerated. True, the possibility of being refused is a disincentive to suitors' search, all other things equal. But the ability to refuse unattractive suitors makes marriage itself more desirable, and so gives a potential partner greater incentive to develop (i.e., invest in) attributes or skills that make him or her more likely to be approached by an acceptable suitor. Because potential partners are then more desirable, there will be more search, by more suitors. 
effect, increased incentive to search, dominates, the externality is a relevant external benefit, and shareholders will prefer that the ability of other targets to resist be strengthened. If the first and second impacts offset each other, the externality is irrelevant and need not be considered further.

Still a fourth condition necessary to justify legal "correction" of a relevant external cost requires that the cost of correction be less than the losses arising from the externality. ${ }^{62}$ In other words, the parties must be missing gains from trade because of some condition remediable by legal authority. By focusing solely on the benefits perceived from a no-resistance rule, Easterbrook and Fischel imply that the costs of correcting externalities due to resistance are negligible, even non-existent. ${ }^{63}$ But as was noted in Part I, losses do arise from using a no-resistance rule to control the externality at issue, because initial investment incentives are altered. In effect, the technique suggested for controlling the perceived externality, non-resistance, has external effects of its own. Other commentators 'have noted still other costs. ${ }^{64}$ Because no determination has yet been made of whether the costs of the original externality exceed or fall short of the costs of the externality created by removing the first, one must fall back on intuition to determine support or opposition for a no-resistance rule-an uncomfortable resolution at best.

The fifth and final condition necessary to justify legal intervention to correct a Pareto-relevant externality is high private costs of internalization relative to the costs of public control. ${ }^{65}$ Government solutions to problems cannot be optimal if private solutions are

02 As Buchanan and Stubblebine note:

[T] he observation of external effects, taken alone, cannot provide a basis for judgment concerning the desirability of some modification in an existing state of affairs. There is not a prima facie case for intervention in all cases where an externality is observed to exist. The internal benefits from carrying out the activity, net of costs, may be greater than the external damage that is imposed on other parties.

Buchanan \& Stubblebine, supra note 6, at 381 (footnote omitted). Buchanan and Stubblebine refer to externalities satisfying this condition as "Pareto-relevant." Id. at 374-75.

6s According to Easterbrook and Fischel, both shareholders and bidders benefit from mandatory non-resistance. Auctions, supra note 2, at 7-9.

of See supra notes 50-52 and accompanying text.

os Demsetz makes the same point:

[P]roperty rights convey the right to benefit or harm oneself or others. ... What converts a harmful or beneficial effect into an externality is that the cost of bringing the effect to bear on the decisions of one or more of the interacting persons is too 
cheaper. This final necessary condition does not seem to be met in the case of tender offers. Private internalization of any relevant externality appears to be available at modest cost, as is explained in the next Part. If so, a no-resistance rule is inappropriate even if all the other necessary conditions for government intervention are met, which is a problematic supposition in its own right.

\section{Private Solutions to the "Problem" of Takeover RESISTANCE}

If resistance generates Pareto-relevant, non-pecuniary externalities, they will be internalized when property rights are well defined and transaction (contracting) costs are low. ${ }^{68}$ The common law has granted target firms unambiguous property rights to resist tender offers. That leaves the other issue: whether other potential targets, the alleged victims of the externalities created by target firm resistance, can achieve contractually the level of bidder monitoring they prefer. If so, they can avoid the external effect that would otherwise exist. If potential targets can credibly bond themselves not to resist a tender offer, outside bidders in the market for corporate control will not reduce their level of scrutiny and monitoring. In that event, government intervention cannot be justified.

The monitoring of targets by bidders is not free; firms that get more of it will pay for the increase. A no-resistance promise, giving more of the expected takeover gain to bidders, is one way to pay for more monitoring. A firm selects the level of scrutiny by selecting the price of being acquired. Non-resistance means a lower expected price and so increases scrutiny. If a firm can credibly promise not to resist a takeover, it cannot be affected by other targets' resistance, and there cannot be any relevant externality.

Those who would ban defensive tactics because of alleged externalities implicitly assume that prospective targets cannot promise not to resist, that bidders cannot cheaply be informed of these promises, or that bidders will not believe the promises. But intrafirm contracts and third-party bonding through the formal rules of the organized stock exchanges allow firms to choose the level of resistance, and thus of monitoring, for which they are willing to

high to make it worthwhile . . . .

Demsetz, supra note 12, at 347-48.

${ }^{60}$ See Coase, supra note 53 , at $15-16$. 
pay. There is, in short, no inevitable pecuniary or technological externality.

\section{A. Shareholder Agreements}

The obvious place for shareholders to invoke a ban on defensive tactics is within the firm itself. In theory, shareholders could use their firms' articles of incorporation to specify the types and amounts of defensive tactics their managers could use. But there are two potential problems with such intrafirm contracts: pre-bid agency problems created by unfaithful managers, and post-bid opportunism against bidders by shareholders.

\section{Pre-Bid Agency Costs}

When ownership is widely dispersed, no one shareholder will find it worthwhile to draft, and to obtain adoption of, corporate charter changes. If changes are to be made, they must originate with management. Easterbrook and Fischel argue that since managers want to keep their jobs, they are unlikely to draft or support charter amendments or changes in bylaws that encourage tender offers. ${ }^{67}$ But other contractual devices-phantom stock plans, stock option plans, and "golden parachute" contracts, for example-can align the interests of managers and shareholders in the event of a hostile tender offer. ${ }^{68}$ Indeed, as Easterbrook and Fischel have recognized in another context, "[p]ublicly held corporations have developed a wide range of governance mechanisms that align managers' interests more closely with those of investors."

Such internal arrangements are admittedly costly, but so is any method designed to induce monitoring. At the other extreme, shareholders might do no internal monitoring, relying instead on increased monitoring from outside bidders. But as noted above, more outside monitoring must be purchased by forgoing takeover premiums so as to promise greater gains to outside bidders. Contractual devices like golden parachutes merely substitute costly

\footnotetext{
${ }^{67}$ Proper Role, supra note 2, at 1175, 1181.

63 See Knoeber, supra note 33, at 159-61; Lambert \& Larcker, Golden Parachutes, Executive Decision-Making, and Shareholder Wealth, 7 J. Acct. \& Econ. 179, 184-85, 200-01 (1985).

69 Easterbrook \& Fischel, Close Corporations and Agency Costs, 38 Stan. L. Rev. 271, 277.78 (1986).
} 
internal monitoring mechanisms for costly external monitoring by bidders. But there is no reason to think that internal monitoring is always more costly, particularly since the internal devices are approved by shareholders themselves.

Suppose arguendo that as takeovers loom, job-conscious managers can frustrate passage of amendments to the articles of incorporation that are in shareholders' interests. This possibility does not dispose of the issue, however. At the time of an initial public offering of securities there is no agency problem, because there is no separation of ownership and control. At this juncture shareholders would pay lower prices for the shares of firms that did not bar defensive tactics, if shareholders unambiguously would benefit from a no-resistance rule. Agency problems evolve subsequently due to the costliness of foreseeing all plausible eventualities. ${ }^{70} \mathrm{But}$ if non-resistance unambiguously maximizes the present expected value of a corporation, it should present no initial difficulties of foresight. The founding shareholders of a corporation have a strong incentive to install internal governance rules that investors consider optimal. If it were indeed value-maximizing to do so, fledgling firms would install stringent rules prohibiting defensive tactics before hiring outside managers, and would install provisions making it hard to alter the anti-defensive rules. Ordinarily they do none of these things.

\section{Post-Bid Shareholder Opportunism}

An objection to the notion that initial charter provisions can limit the resistance that bidders will expect arises from the ability of shareholders to change their charter opportunistically when a takeover is anticipated. Post-bid resistance is profitable. Any firm can adopt and announce a policy forbidding defensive tactics, but target shareholders can revoke the earlier policy and create an auction market after a bid is launched. Shareholders of all firms would be harmed if bidders could not distinguish firms that are likely to resist a bid from those that are not. ${ }^{71}$ If bidders cannot distinguish, perhaps new law is called for, but only to ensure that firms honor

\footnotetext{
70 See Grossman \& Hart, supra note 30 , at 48 .

7 Actually, few firms would keep tbeir promises if bidders could not tell the difference. See Akerlof, The Market for "Lemons": Quality Uncertainty and the Market Mechanism, 84 Q.J. Econ. 488, 495-96 (1970).
} 
their promises to refrain from resistance, not to bar all resistance.

But this point seems moot. Firms can credibly bind themselves not to resist. Time is of the essence in struggles for corporate control. Shareholders can insert one provision in their charters to forbid all defensive tactics (or a specified subset) and another to prevent any changes in the charter until a specified period has passed. Such provisions would protect bidders from shareholder opportunism unless bidders were forced to reveal their intentions far in advance of their takeover move. ${ }^{72}$

Even without such delaying provisions, the structure of the corporate governance process prevents shareholders from making rapid changes in their articles of incorporation. Substantive changes require a shareholder vote, ${ }^{73}$ which takes time, particularly if shareholders are widely dispersed. Furthermore, the mechanisms of soliciting proxies are controlled by federal rules ${ }^{74}$ which again create delay. These delays give prospective bidders additional assurance that firms banning defensive tactics cannot change their articles before a transfer of control occurs.

These bonding mechanisms are not "perfect," i.e., costless. But again, as with internal monitoring devices and the control of externalities, the cost of bonds must be compared to the costs of alternatives. It may be that a legal rule would provide enforcement of firms' no-resistance promises more cheaply than would private bonding. If so, the appropriate legal response is to enforce voluntarily offered target promises rather than to ban all resistance. If firms are truly better off eschewing resistance, such a legal rule would allow them to choose credible no-resistance policies. If shareholders do wish to allow bargaining, however, the rule would

72 Perhaps the Williams Act, Pub. L. No. 90-439, 82 Stat. 454 (1968) (codified as amended at 15 U.S.C. \$\$ 78l-78n (1982 \& Supp. III 1985)), has forced bidders to reveal their intentions so far in advance that preexisting corporate charters now offer insufficient restraints on resistance. But if that is so, the solution is not more law, hut less-repeal or modification of the Williams Act.

7s See, e.g., Revised Model Business Corp. Act, $\$$ 10.01-.03 (1985); Del. Code Ann. tit. 8, $\S 242$ (b)(1)-(2) (1974).

7 The solicitation of proxies is controlled by the Securities Exchange Act, $\$ 14,15$ U.S.C. $\S 78 \mathrm{n}$ (1982 \& Supp. III 1985), and by Regulation 14A of the Securities and Exchange Commission, 17 C.F.R. $\$ 240.14$ a (1986). SEC Rule 14a-6 requires that five copies of all proxy statements and accompanying forms be filed with the SEC ten days prior to the date such material is given to stockholders, 17 C.F.R. $\$ 240.14 a-6(a)$ (1986), although the SEC may authorize a reduction in the ten-day period "upon a showing of good cause therefor." Id. 
not preclude this possibility. Unlike the Easterbrook-Fischel proposal simply to ban resistance, a bond-enforcing rule would not bring with it the risk of firms losing the benefits of bargaining detailed in Part I.

\section{B. Third-Party Bonds}

When doubts exist about contractual reliability outside the corporate control market, third-party bonding to assure performance often resolves them. ${ }^{75}$ Similarly, bonding could be used in the corporate context to ensure that firms promising to refrain from resisting outside bids will keep their promises. An explicit or implicit no-resistance bond could be posted with a third-party fiduciary, its value exceeding the expected gains from resisting once a bid materialized. The bond would be forfeited if the firm breached its promises. If credible mechanisms exist to bond shareholders to their promised responses to takeover bids, firms can choose their desired level of bidder monitoring by adjusting the contractual level of resistance.

State laws barring resistance by target firms comprise one possible sort of third-party bond. It is often suggested that state corporation statutes, reflecting interstate competition for charter revenues, furnish the most efficient rules of corporate governance. ${ }^{78}$ If so, some states could enact no-resistance rules, and firms desiring to bond themselves to those rules could incorporate there. By subjecting themselves to suit if they violated the statute, firms would bond themselves not to resist. Thus the observed failure of states

75 See Knoeber, An Alternative Mechanism to Assure Contractual Reliability, 12 J. Legal Stud. 333, 335-43 (1983) (describing the merits and costs of third-party bonding arrangements, particularly in tbe farming industry); Klein \& Leffler, The Role of Market Forces in Assuring Contractual Performance, 89 J. Pol. Econ. 615, 635-37 (1981) (suggesting that third-party enforcement is often the cheapest method of assuring performance).

${ }^{76}$ See R. Winter, Government and the Corporation 7-11 (1978); Fischel, The "Race to the Bottom" Revisited: Reflections on Recent Developments in Delaware's Corporation Law, 76 Nw. U.L. Rev. 913, 919-20 (1982); Winter, State Law, Shareholder Protection, and the Theory of the Corporation, 6 J. Legal Stud. 251, 289-92 (1977). But see Cary, Federalism and Corporate Law: Reflections upon Delaware, 83 Yale L.J. 663, 666 (1974) (competition among states for revenues has led to permissive corporation statutes which "have watered the rights of shareholders vis-à-vis management down to a thin gruel"); Fischel, Efficient Capital Market Theory, the Market for Corporate Control, and the Regulation of Cash Tender Offers, 57 Tex. L. Rev. 1, 29 (1978) (competition among states may not be effective because a "corporatioll may be subject to the tender offer statutes of several states even if incorporated in a state with no sucb statute"). 
to adopt a no-resistance rule may suggest that firms do not demand bonding. ${ }^{77}$

If, for some reason, bonding through state law proved insufficient, the organized stock exchanges could serve as third-party guarantors of firms' promises of non-resistance. The exchanges have incentives to devise rules maximizing listed firms' values. ${ }^{78} \mathrm{~A}$ firm will select as its forum for trading the exchange with the best rules for that firm's circumstances.

Originally, simply listing on the New York Stock Exchange (NYSE) assured prospective bidders that the firm would not violate the exchange's rules. In the days before sophisticated computer technology, the NYSE was a natural monopoly. Firms that flouted exchange rules were delisted and lost access to this central marketplace, with a consequent fall in the firm's share prices. The long-term prospective loss of liquidity from delisting imposed costs on shareholders that reduced the attraction of short-term gains from violating exchange rules.

Thus if firms could have gained by having enforceable no-resistance rules, the NYSE should have had them. Long before federal regulation of securities trading, the NYSE required independent audits and certain timely disclosures, and specified shareholder

77 Cf. Romano, Law as a Product: Some Pieces of the Incorporation Puzzle, 1 J.L. Econ. \& Organiz. 225, 265-73 (1985) (statistical analysis indicates that firms experience positive returns as a result of reincorporating in Delaware to deter takeovers). At first blush it may seem that an individual state will be unable to enforce its statute forbidding resistance. A firm might initially locate in a state with strict limitations on defensive tactics, but then reincorporate in a lenient state when a takeover seems imminent. But a state mandating non-resistance could require all firms incorporating there to post a monetary hond, which would be forfeited if the firm exited the state when a takeover threatened.

Another problem with relying on states to provide bonding services for firms wishing to make credible promises of no resistance is that individual states may, for their own reasons, prefer to encourage rather than help discourage resistance. States with strict statutes forbidding resistance would lose tax revenues from firms that were taken over by corporations outside of the state, and these losses might not be offset by the increased revenues from chartering that came from providing a no-resistance rule. If that were true, of course, the value of no-resistance bonding to firms, and, hence, to the states would have to be modest. Otherwise, at least one state would make a market in no-resistance charters, because the revenue-maximizing level of fees is endogenous, increasing as the number of closely competing states declined.

${ }^{78}$ See Easterbrook, Managers' Discretion and Investors' Welfare: Theories and Evidence, 9 Del. J. Corp. L. 540, 556 (1984) [hereinafter Managers' Discretion] ("The willingness of people to trade depends . . . on their belief that they will get a fair deal. Thus it is in the interest of stock exchanges to establish rules for the protection of investors, and managers who seek to attract money will submit to these rules."). 
voting rights for listed firms. ${ }^{79}$ But the NYSE has never had anything like a general no-resistance rule. Only two NYSE rules conceivably could be construed as discouraging defensive tactics, and these also serve purposes unrelated to takeovers. Listed firms must obtain shareholder approval before issuing new stock exceeding eighteen percent of the value of the firm's outstanding stock, ${ }^{80}$ and dual classes of voting stock are not allowed. ${ }^{81}$ But the most common sorts of resistance-shark repellants, greenmail and the like-have never been limited by the NYSE. The absence of NYSE rules forbidding defensive tactics seems inconsistent with the argument that the market's anticipation of resistance to a takeover decreases a firm's value.

There are indications that technological innovations have raised the ex ante costs of bonding through listing on the NYSE. Today, with cheap electronic communications available to everyone, the NYSE faces competition from the over-the-counter market and other exchanges. The presence of these rivals has diminished the value of the bond that NYSE listing once represented to prospective bidders. ${ }^{82}$ Although the emergence of rival markets might explain why no exchange has adopted rules forbidding defensive tactics, it is significant that the NYSE never adopted rules forbidding resistance even when it had little fear of losing listings.

But despite the modern competition among them, the exchanges

79 Benston, Security for Investors, in Instead of Regulation 169, 170 (R. Poole ed. 1982); Watts \& Zimmerman, Agency Problems, Auditing, and the Theory of the Firm: Some Evidence, 26 J.L. \& Econ. 613, 629 (1983).

so Managers' Discretion, supra note 78 , at 556 .

B1 But see NYSE Formally Submits Proposal To Allow Unequal Voting Rights, 18 Sec. Reg. \& L. Rep. (BNA) No. 37, at 1337 (Sept. 19, 1986) (NYSE submits plan to SEC for allowing two stock classes with unequal voting rights, to prevent migration to other exchanges); id. at 1389 (text of proposed changes in NYSE rules).

${ }_{82}$ Neither the National Association of Securities Dealers (the industry self-regulatory organization that governs trading in the over-the-counter market) nor the American Stock Exchange forbids its listed firms' from adopting dual stock classes with unequal voting rights. Recently, several NYSE-listed firms considered to be likely takeover targets violated exchange rules by adopting dual classes of stock with different voting rights (so-called "super shares") to avoid hostile takeovers. See Gordon, Ties That Bond: Dual Class Common and the Problem of Shareholder Choice, 75 Calif. L. Rev. (forthcoming Oct. 1987). Rather than enforce its rule and lose listings to these competing markets, the NYSE has proposed changing its rules regarding voting rights for common stock. See supra note 81 . At present, though, a firm can claim to be bonding itself not to engage in certain defensive tactics by listing on the NYSE, but then jump to another exchange or to the over-thecounter market when a bidder commits himself. 
still represent separate legal entities with standing to sue, a standing that is not contingent on the contracting party remaining listed on that exchange. The emergence of rival exchanges means only that listing firms no longer bond themselves automatically to obey the rules of specific exchanges. Firms can sign legally enforceable bonding contracts with the exchanges. A firm could voluntarily bond itself by signing a contract with an exchange specifying a sum that the firm would forfeit if it resisted a hostile bid for control. ${ }^{83}$ The bond would lessen the gains that a target might realize from defensive tactics. If shareholders valued such bonds, exchanges themselves would benefit from serving as guarantors or bonders, by providing a service of value to their listed firms and so being able to share in any of the resulting gains.

Because target firms can post bonds with exchanges, firms that desire more outside surveillance by potential bidders can purchase it, though two transactions (listing and bonding) may now be required where one sufficed earlier. External bonding admittedly is costly - as is any other device to obtain the level of monitoring the firm wants. The point is, first, that institutions with an incentive and an ability to bond targets' promises already exist. Moreover, the costs of writing effective and enforceable bonds appear to be slight, compared to the obviously costly alternative of banning valuable resistance. If Easterbrook and Fischel are correct that future target firms are systematically the victims of present target resistance, it is remarkable that none of the entities with an interest in the problem has done anything to solve it.

\section{Firm Variety and Legal Default Rules}

The amount of resistance the firm chooses, relying where necessary on bonds to bolster its pledges, determines the amount of external monitoring it receives in the market for corporate control. Firm owners can combine this external monitoring with internal governance mechanisms of their own, depending on the relative prices of external and internal devices, to achieve the optimal set of monitoring inputs overall. But different firms will demand varying amounts of monitoring, since they have managers with different attributes, industrial structures posing different problems, and

ss See Knoeber, supra note 75 , at $335-36$. 
different organizational practices. Likewise, to achieve a given level of monitoring, different firms will find it optimal to mix different amounts of the various monitoring inputs available. ${ }^{84}$

A principal disadvantage of a no-resistance rule is its inflexibility in the face of firms' demands for different types and degrees of monitoring. ${ }^{85}$ A no-resistance rule forces at least some firms to buy more outside monitoring than they want. There is no such thing as the efficient amount of external monitoring inputs across firms, any more than there is a single optimum amount of labor or capital across all firms in all industries. Railroads have different capitallabor ratios than do drycleaning establishments. Similarly, different firms will prefer different combinations of external and internal monitoring inputs.

Casual empiricism verifies this phenomenon. Shareholders in many firms have agreed to restrict the payment of greenmail, or have refused to install poison pill provisions in their charters. Others have not. ${ }^{86}$ Internally, many firms have stock option plans and golden parachute agreements. Others do not.

In the face of such diversity in the use of monitoring inputs, the law's attempts to correct supposed imperfections must be cautious. The corporation is itself a set of contracts linking shareholders, di-

84 See Managers' Discretion, supra note 78, at 543-53; Jensen, supra note 15, at 324. Shareholders have other mechanisms besides the market for corporate control to monitor managers, sucb as frequent trips to the capital markets, which subject firms to the scrutiny of investment banks and otber institutional monitors. See Easterbrook, Two Agency-Cost Explanations of Dividends, 74 Am. Econ. Kev. (Papers \& Proc.) 650, 652-56 (1984); Jensen, supra note 15 , at 324 . Use of outside auditors, independent directors, and management consultants can also be an effective monitoring device. In addition, the market for managerial labor rewards and punishes managerial performance as appropriate. All else being equal, shareholders who utilize more of these other monitoring devices will demand less monitoring by takeover bidders, and will want their firms to engage in more defensive tactics in order to realize the full value of their monitoring activities.

8s "Politics is the art of compromise because political outcomes are very indivisible. The greater divisibility of market outcomes makes business the art of serving new wants without compromising old ones." H. Demsetz, Economic, Legal, and Political Dimensions of Competition 76 (1982). Perhaps this discussion seems to overstate a firm's ability to "fine tune" the allowable resistance prospectively. But a court does not have perfect foresight either. Judicial enforcement of a uniform and compulsory no-resistance rule would provide less flexibility than would interpretation of a voluntary no-resistance contract.

${ }^{86}$ See Baysinger \& Butler, Antitakeover Amendments, Managerial Entrenchment, and the Contractual Theory of the Corporation, 71 Va. L. Kev. 1257, $1257-59$ (1985). Baysinger and Butler note that, though "many large corporations have adopted charter and bylaw amendments tbat discourage unsolicited tender offers," not all corporations have adopted such devices. Id. 
rectors, managers and others. ${ }^{87}$ The role of corporate law thus is enforcement of the explicit terms of the contracts, plus the more difficult default role of supplying terms to cover contingencies that the contracting parties did not explicitly contemplate in the contracts. As Easterbrook and Fischel note, corporate law should supply 'standard form 'contracts' of the sort shareholders would be likely to choose." 88

The desirability of legal default rules diminishes as the number of plausihle choices available to the contracting parties increases. When, as in the takeover setting, there are dozens of internal and external monitoring choices available, and thus many thousands of possible input combinations, the likelihood that an appreciable number of firms would choose extremely large or extremely small amounts of many of those inputs is practically nil. Yet that is what a no-resistance rule would accomplish, by prohibiting firms from purchasing any combination of inputs that did not maximize outside monitoring. Such a rule would force an appreciable number of firms to purchase more external monitoring (thus inducing less internal monitoring) than they would prefer. It is unlikely, that is, that many shareholders would wish to write the sort of contract that Easterbrook and Fischel's no-resistance rule would impose upon them.

As a standard-form contract for shareholders, the EasterbrookFischel proposal has a second defect. While a legal default rule merely forces all firms to accept the same missing term when they fail to provide for some contingency, the Easterbrook-Fischel proposal would override the explicit terms of charter provisions, employment agreements, and the like, when those contracts allowed managerial resistance to takeovers. Easterbrook and Fischel's rule is thus not a default option, around which firms can contract as they please. Rather, it mandates a set level of resis-

87 See R. Posner, supra note 38, at 369-72; Alchian \& Demsetz, supra note 28, at 787-88; Baysinger \& Butler, supra note 86 , at $1285-88$.

ss Proper Role, supra note 2, at 1182. Assigning the default role to the law does not determine which legal institution will be responsible for filling in corporate contracts. Judges can supply missing contractual terms case by case. Or, the legislature can lay down a single rule to cover all contingencies. Each system has its benefits and costs. Judicial resolution of controversies permits consideration of the particularities of each case, but may be more timeconsuming. Legislative action may consume less time, but a single rule that is applied to all situations may not fit the facts of a particular case. 
tance-zero-regardless of the level shareholders have chosen. A no-resistance rule would effectively tear up those resistance-authorizing charter provisions to which shareholders themselves have agreed.

No legal rule in this area can be optimal unless it is an option. Firms that wish to avail themselves of the option can thereby lower transaction costs by not drafting and negotiating specific provisions in their contracts. But not all firms will find the legal prescription that is chosen appropriate. The ability of firms to contract around costly legal rules when lower-cost private alternatives are available must be a feature of any efficient standard-form contract.

Default options, like everything else, have their costs. In the takeover context, they may create uncertainty among bidders about what resistance rules a particular target has in force. But institutions like stock exchanges make it their business to minimize these costs. Moreover, firms that adopt no-resistance rules thereby increase the potential gains available to bidders in order to attract increased takeover attention. These firms then have every incentive to let bidders know what they have done, and bidders have every incentive to search for that information. In short, then, the legal system should limit itself to providing a default option, rather than imposing a no-resistance rule that overrides the rules that firms may wish to provide for themselves.

Of course, permitting firms to contract around legal rules means that courts must sometimes interpret and enforce contracts. But a rule requiring managerial passivity in the face of a takeover bid also requires costly interpretation and enforcement. As Easterbrook and Fischel concede, "many legitimate business decisions could have the effect of making the corporation less attractive to the bidder and thus could be called resistance. . . . Distinguishing resistance from passivity will be simple in some cases and hard in others." 89

Nor does it follow that corporate contracting should be ignored in the takeover context because some forms of resistance, such as poison pills or greenmail, were unknown at the time contracts were written. Legislatures are no more capable of predicting appropriate rules for things that do not exist than are the original entrepre-

\footnotetext{
s9 Id. at 1202.
} 
neurs. Whatever statutory language a legislature might choose to proscribe takeover defenses is equally available to firms themselves if they want to use it.

\section{Agency Costs}

Whether or not important externalities attend takeover resistance, Easterbrook and Fischel believe resistance is undesirable because managers will resist to save their jobs, not to benefit their shareholders. ${ }^{90}$ Indeed, to Easterbrook and Fischel the very existence of tender offers shows agency problems in target firms. Combinations between firms could occur through friendly mergers, which they claim dissipate fewer resources than hostile tender offers. ${ }^{91}$ A bidder's resort to a tender offer, Easterbrook and Fischel argue, reveals target firm managers to have been protecting themselves by refusing to facilitate a beneficial merger alternative for shareholders. ${ }^{92}$

Mergers remain by far the most prevalent form of interfirm combination, while tender offers are comparatively rare. ${ }^{93}$ This observation suggests that significant agency costs do not typify the takeover process, even by Easterbrook and Fischel's standards. It is also noteworthy that, for Easterbrook and Fischel, agency costs seem to be a significant problem only for tender offers. As Easterbrook has reported elsewhere, overwhelming empirical evidence from various aspects of corporate governance suggests that faithful managers are rewarded while the faithless are punished..$^{94}$ Shareholders apparently do monitor, and do devise corporate governance

${ }^{\circ}$ Id. at 1174-75. According to Easterbrook and Fischel, target firm managers create no wealth in the corporate control market. Rather, they reduce wealth by resisting takeover attempts in order to save their jobs. In the Easterbrook and Fischel model, only bidders create wealth, by locating and acquiring undervalued assets and transferring them to highervalued uses. Id at 1173-77. But as Part I noted, the takeover process involves inputs from targets, bidders, and broker-intermediaries such as investment bankers.

11 Id. at 1169 (benefits of takeovers "could be achieved by friendly merger as well as by hostile tender offer," but a "tender offer is by far the more costly device"). To support this empirical claim, Easterbrook and Fischel cite a study of tender offer costs, but offer no data concerning the cost of mergers. See id. at 1169 n.22.

22 See id. at 1169, 1174-75.

${ }^{93}$ For a summary of the data, see Knoeber, supra note 33, at 155 n.1. In 1982, the most recent year reported, tender offers constituted only four percent of all acquisition announcements.

or Managers' Discretion, supra note 78, at 547-52. 
mechanisms that impose the costs of agency on agents themselves. $^{95}$ In advocating a no-resistance rule, Easterbrook and Fischel do not explain why tender offers are unique.

Especially curious is Easterbrook and Fischel's preference for mergers, rather than takeovers, to avoid agency costs. The potential for agency problems is no less in friendly mergers than in hostile tender offers. Managers of firms acquired in friendly mergers often receive substantial lump-sum payments from the acquiring firm or, alternatively, job guarantees for themselves prior to submitting the proposal to shareholders. ${ }^{96}$ Moreover, managers typically do not accept the first bid from the prospective partner. Rather, they "resist" by bargaining for a better deal before submitting the offer for shareholder consideration. In negotiating merger terms, target firm managers seem to extract much, if not all, of the available gain from the combination, leaving the bidding firm with only a competitive rate of return. ${ }^{97}$ Such hard bargaining presumably decreases the interest of other bidders in seeking merger targets, which again means less monitoring throughout the economy. If mergers are preferable to hostile tender offers, why is managerial resistance appropriate for the former but not the latter? ${ }^{98}$

This is not to deny that resistance (in the face of either merger offers or tender offers) can sometimes be used opportunistically by management. ${ }^{98}$ But as Part I pointed out, the ability to resist also

${ }^{95}$ Demsetz expresses similar skepticism about the importance, relevance, or even meaning of agency costs. See Structure of Ownership, supra note 24; cf. Alchian, Corporate Management and Property Rights, in Economic Policy and the Regulation of Corporate Securities 337, 344-47 (H. Manne ed. 1969) (agency costs are higher because of dispersion of control among shareholders, but other advantages of this form of enterprise outweigh those costs).

os See, e.g., Hawkins, Tull Execs Guaranteed Pay for 3 Years in Buy-Out Plan, Atlanta Const., Mar. 27, 1985, at B3, col. 5 .

97 See Jensen \& Ruback, supra note 16, at 9-16.

98 Easterbrook and Fischel also overlook the fact that management's ability to enhance gains in merger negotiations depends on its ability to resist tender offers. A bidder encountering hard bargaining for a merger can go directly to shareholders by launching a tender offer. A target's tough line in merger negotiations is not credible if management can do nothing against a tender offer to force the bidder back to the merger bargaining table.

By the same token, a bidder's ability to resort to a hostile tender offer tempers the demands that a target can make at the merger table. The acquisition of Sperry by Burroughs illustrates how a bidder can try to outmaneuver a target by combining a hostile tender offer with a friendly merger offer. See Crudele, Persistence Pays Off in Burroughs Deal, N.Y. Times, May 28, 1986, at D1, col. 4; Buss \& Hertzberg, Sperry Is Said To Meet Today on Higher Bid, Wall St. J., May 27, 1986, at 3, col. 4.

- Partly because there are so many reasons behind corporate takeovers, see supra notes 
can convey long-run benefits to shareholders. Whenever use of a tool such as resistance creates both costs and benefits for shareholders, they will want to optimize rather than eradicate its use.

15-16 and accompanying text, the empirical studies often cannot distinguish between desirable and undesirable takeover activities. See Roll, The Hubris Hypothesis of Corporate Takeovers, 59 J. Bus. 197 (1986). Moreover, the empirical evidence on the effects of management resistance to takeover bids is itself complex and often contradictory. Empirical studies on greenmail, for example, are equivocal, but seem to indicate that target firms are better off when a raider buys into them and then is paid greenmail for his shares than they would be if greenmail were banned. See Macey \& McChesney, supra note 7, at 43-48. Likewise, shareholders apparently benefit when management resists takeovers ex post by filing antitrust actions. Jarrell, supra note 53, at 175. Study of ex ante antitakeover amendments has generated more inconclusive results. DeAngelo and Rice find that such amendments produce insignificant results on adopting firms' share prices. DeAngelo \& Rice, Antitakeover Charter Amendments and Stockholder Wealth, 11 J. Fin. Econ. 329, 355 (1983). Linn and McConnell find that such amendments have significant positive effects on adopters' share prices. Linn \& McConnell, An Empirical Investigation of the Impact of "Antitakeover Amendments" on Common Stock Prices, 11 J. Fin. Econ. 361, 397 (1983). A study by the SEC's Office of the Chief Economist, on the other hand, finds that antitakeover amendments have significant negative effects on share prices, although one type of amendment, fair-price provisions, has no effect at all. See Office of the Chief Economist, SEC, Shark Repellents and Stock Prices: The Effects of Antitakeover Amendments Since 1980, at 43 (July 24, 1985). This evidence is especially curious because the amendments studied were "[a]lmost always subject to approval by majority vote of shareholders." Id. at 1.

In addition, a defensive tactic may hurt some but not all of the firms that adopt it. This is shown by another study by the Office of the Chief Economist, which looks at share price changes in firms adopting poison pills. Office of the Chief Economist, SEC, The Effects of Poison Pills on the Wealth of Target Shareholders (Oct. 23, 1986). The study concludes that such devices have significant negative effects overall. Id. at 43 . But it finds that, of firms adopting poison pills during control battles, the number that lost value when the pill defeated the takeover equaled the number that gained when the pill led to a later takeover at a higher price. Id. at 41 . Such equivocal evidence hardly justifies a rule that supposedly would benefit firms that might not want a poison pill, but would prevent an equal number of firms from using a pill to benefit themselves.

Thus, the empirical case for banning resistance to takeovers is as unsettled as the theoretical argument. The empirical case, however, is largely irrelevant to our argument here. The typical event study examines the effect of a defensive tactic at the time it is imposed, normally as a response to a takeover bid. See, e.g., Dann \& DeAngelo, Corporate Financial Policy and Corporate Control: A Study of Defensive Adjustments in Asset and Ownership Structure (rev. ed. Aug. 1986) (Managerial Economics Research Center, University of Rochester, Working Paper No. 86-11) (finding that managerial responses to attempted hostile takeovers by changes in asset or ownership structure have significant negative effects on firm share prices). Even if agency costs are significant at the time of an attempted takeover, the benefits of having a bargaining rule in effect will long since have been incorporated into share prices. An event study at the time of the takeover will miss these benefits. 


\section{Conclusion}

The foregoing discussion has analyzed the role of bargaining in the context of alternative structures of property rights, and has applied that analysis to bargaining for corporate control. Bargaining is the hallmark of exchanges in thin markets. It is no accident that maximizing the value of assets often requires investments that owners cannot expect to be valued accurately by "objective" techniques, but only by negotiation. By definition, these investments involve more asset-specific risk, the management of which requires asset-specific investments in human capital. That capital can be expropriated unless bargaining is permitted.

It would be astounding if weakening well-defined property rights increased welfare. An externally imposed rule substituting liability for property protection can benefit neither bidders nor targets. It reduces the incentive to create value in potential targets. It causes too many bidders to search too much, too soon. There are good reasons why such a rule is not observed in other thin markets, even those in which sellers commonly use agents, and in which the good-faith efforts of the agent are costly to measure.

In baseball, for example, putting a player on revocable waivers creates the same sort of externality decried by Easterbrook and Fischel. If a claim is made for the player on waivers, the team owning his contract can revoke the waivers and either keep the player or begin bargaining with the team filing the claim. The bidding team has spent real resources evaluating the player relative to its own circumstances, and the ability to revoke the waivers may well reduce the number of bids. Yet all teams mutually agree to the system of revocable waivers as part of the rules of major-league baseball; presumptively therefore, it is optimal for baseball teams as a group. There is nothing special about corporate control that would justify a different rule for tender offers.

Unfettered discretion by asset owners over future bargaining strategies cannot be shown to be inferior to a mandatory no-resistance rule. Target firms can contract for any level and type of monitoring for which they are prepared to bear the unavoidable resource costs. If they wish, they may bond through both internal and external means any no-resistance promise they may make to potential bidders. The externality problem is a mirage. Imposing a single rule on firms with varying demands for outside monitoring would itself create inefficiencies where none now exist. 
If the legal structure currently will not enforce voluntary commitments not to resist, the appropriate legal change is to enforce those promises, not to require non-resistance as a matter of law. Admittedly, judicial ability to interpret voluntary commitments is neither costless nor perfect. But to require costless perfection of a policy is to succumb to the Nirvana fallacy. The appropriate standard is not perfection but a real-world alternative. Against that standard it is difficult to imagine how voluntary commitments can be more costly to enforce than are compulsory ones.

Management had a lesser role in tender offers before the Williams Act established mandatory waiting periods during which tenders cannot be completed. ${ }^{100}$ The delay now required gives target managers greater opportunity to employ a variety of defensive tactics (e.g., poison pills, greenmail, and share repurchases) to fend off first and even subsequent bids. By lengthening the period over which tender offers are outstanding, the Williams Act may have weakened implicit commitments not to resist. But if so, the solution is to repeal or modify the Williams Act, not to add a new layer of immobilizing constrants. ${ }^{101}$

As noted at several junctures above, resolution of all aspects of the controversy over resistance, particularly the externality issue, cannot be done at a purely theoretical level; some empirical judgments are required. Neither the proponents nor the opponents of managerial bargaining have provided quantitative evidence to support their position. But surely, given that low-cost private contractual solutions are available to solve any externality, and given that practically all other thin markets have evolved exchange rules allowing bargaining, the burden of persuasion must be on those who would ban bargaining. Likewise, firms differently situated inevitably want different bargaining rules, and are observed to impose different rules on themselves. Consequently, opponents of bargain-

\footnotetext{
${ }^{100}$ See 15 U.S.C. $\S 78 \mathrm{n}(\mathrm{d})(5)$ (1982) (provision indirectly forcing all offers to remain open at least seven days, by allowing shareholders to withdraw proffered shares during that period); 17 C.F.R. \$ 240.14d-7(a)(1) (1986) (SEC rule extending the minimum offering period to 15 business days from the commencement of the tender offer); id. $\S 240.14 d-7$ (a)(2) (SEC rule extending period of offer for 10 business days after another bidder has entered a competing bid for the same class of securities).

${ }^{101}$ In any case, if the interest groups benefited by the Williams Act are too powerful to permit its repeal or modification, they probably can avoid its indirect gutting as well. If so, indirect attacks on the Williams Act are doomed, and need not occupy our time and energy further.
} 
ing must shoulder the burden of showing why these private contractual solutions are undesirable, and why a single rule for all firms would be an improvement. 